\title{
Fundraising Management Optimalization of Zakat Infaq and Alms in The Countryside
}

\author{
Hendri Hermawan Adinugraha \\ Faculty of Economic \& Business, Dian Nuswantoro University Indonesia \\ E-mail: hendri.hermawan@dsn.dinus.ac.id
}

\begin{abstract}
The purpose of this study is to find out how to optimize the ZIS (Zakat, Infaq and Shadaqah (alms)) fundraising through rural community activities. The research location is located in Mergolangu village, Wonosobo District. This research uses an analytical descriptive approach of qualitative and is equipped with relevant literature sources. Data analysis techniques using Miles and Huberman interactive model. The results of this study indicate that the management of ZIS fundraising through community activities in Mergolangu Village is quite effective, this can happen because it still maintains the customs and traditions in the village that are always oriented to the harmony of citizens and local wisdom. So that the residents are still very enthusiastic in following the social activities in rural areas coupled with the activities of accumulating ZIS funds, although with the nominal relatively not too much but because of the regular activities of the ZIS funds are also collected a lot. The distribution system uses the principle of "from citizens, by citizens, and for citizens" as a manifestation of the icon "gotong-royong" typical of Indonesia.
\end{abstract}

Keywords: optimization, social activities, villages, and ZIS.

\begin{abstract}
Abstrak
Tujuan dari penelitian ini adalah untuk mengetahui bagaimana mengoptimalkan penggalangan dana ZIS (Zakat, Infaq dan Shadaqah (sedekah)) melalui kegiatan masyarakat pedesaan. Lokasi penelitian terletak di desa Mergolangu, Kecamatan Wonosobo. Penelitian ini menggunakan pendekatan deskriptif analitis kualitatif dan dilengkapi dengan sumber literatur yang relevan. Teknik analisis data menggunakan model interaktif Miles dan Huberman. Hasil penelitian ini menunjukkan bahwa pengelolaan penggalangan dana ZIS melalui kegiatan masyarakat di Desa Mergolangu cukup efektif, hal ini dapat terjadi karena masih mempertahankan adat istiadat dan tradisi di desa yang selalu berorientasi pada keharmonisan warga dan kearifan lokal. Sehingga warga masih sangat antusias mengikuti kegiatan sosial di daerah perdesaan ditambah dengan kegiatan mengumpulkan dana ZIS, meski dengan nominal relatif tidak terlalu banyak tapi karena terus menerus maka dana ZIS juga banyak terkumpul. Sistem distribusi menggunakan prinsip "dari masyarakat, oleh masyarakat, dan untuk masyarakat" sebagai manifestasi dari ikon "gotong-royong" khas Indonesia.
\end{abstract}

Kata Kunci: Optimalisasi, aktivitas sosial, desa, dan ZIS. 


\section{Introduction}

Poverty is often a classical problem faced by all nations including Indonesia. Even in some backward village household expenditure to meet the needs of daily life insufficient, whereas primary commodity prices for households in the world market increasingly soared, is an impact on the inability of poor people to pay for household needs (Rosyadi et al, 2012 : 304). The majority of Indonesian people are Muslim, this is a potential asset in collecting social funds especially zakat, because zakat is a duty for a Muslim while infaq and alms by sharia are only a sunnah. According to religious perspectives, poverty can be minimized by the support of people who surplus property in the form of giving ZIS to those who deficit property (eight ashnaf). Because in principle ZIS is one of the strategic instrumental value that has a positive effect or impact on poverty alleviation, economic development of a nation and the behavior of one's economy in society (Saefuddin, 1987: 77). Which the Central Bureau of Statistics (BPS) recorded the number of poor Indonesians as of March 2014 of 28,280,010 people or $11.25 \%$ of the total population of Indonesia (RZ Magazine, 2014). So that
ZIS is one of the applicative instrument to support the prosperity of life in the world and hereafter in the form of socio-economic welfare. Therefore, it is necessary to establish Islamic philanthropic institutions as an effort to tackle the social problem.

The function of ZIS as one of the sources of socio-economic funding for mankind can be seen from the utilization of ZIS funds managed by Amil Zakat Institution or Agency for the economic activities of the ummah, such as in aid program, compensation and business capital. The value of ZIS religiosity can be seen through: 1) the belief of ZIS as a religious call. It is a reflection of one's faith.

2) ZIS financial resources will never stop. That is, people who pay zakat, will never run out and who have paid every year or another period of time will continue to pay. 3) ZIS empirically can remove social inequality and vice versa can create a redistribution of assets and equitable development (Ridwan, 2005: 45).

The motivation of someone to spend ZIS funds according to Tarar and Madiha (2012: 89), among others, are: 1) the desire of Indonesian Muslims to complete the implementation of religious teachings. After establishing the prayers, 
fasting during the month of Ramadan and even performing the pilgrimage to Mecca, Muslims are increasingly aware of the necessity of zakat settlement as a religious duty in fulfilling the pillars of Islam. 2) Increasing awareness among Muslims about the potential of zakat if best utilized, will be able to solve various social problems in Indonesia.3) Efforts to realize the development and management of ZIS in Indonesia are more advanced and rapid (Ali, 1988: 53).

There are several reasons for the urgency of the role of economic ZIS of a nation. 1) almost $90 \%$ of the Indonesian population is Muslim so that the existence of zakat is very acceptable as one of the instruments of development and ZIS including one of the pillars of Islam that must be run as well. Secondly, the charity is a clear form of expenditure placement to eight ashnaf especially the poor, in Indonesia is very applicable ZIS all especially with the condition of $60 \%$ of Indonesia's population is under the poverty line. 3) ZIS an economic instrument that is dominated by social values that ZIS be given full rights every mustahiq (the person who is receiving zakat) without warranty of any kind and does not need to be returned to the Institute or Amil Zakat and muzakki (the person who is giving zakat) as befits the loans in the conventional financial institutions.

Based on the results of a survey conducted IPB Center for Islamic Studies conducted in 2013 that the zakat potential in Indonesia reached the amount of $\mathrm{Rp}$ 270 trillion. However, the realization of zakat fund management, mainly from the new zakat māl collected amounting to $\mathrm{Rp}$ 2.4 trillion (http://kabar24.bisnis.com) (Source: Report of Chairman of Zakat Forum Sri Adi Bramasetia). For example, according to Chairman of Baznas KH Didin Hafidhuddin, the acquisition of zakat collected by National Amil Zakat Agency (Baznas) in 2013 reached $\mathrm{Rp} 2.5$ trillion. This makes the average acquisition zakat since the last five years reached 24.46 percent (http://www.republika.co.id).

From these data, it can be seen that the achievement of the zakat potential in Indonesia is still far from its potential, disparity far enough away so that still needs to be synergy for optimizing the collection of ZIS in the framework of efforts to improve people's welfare, reduce unemployment, boost the status of mustahik to muzaki and support the 
economy of Indonesia (Baznas Report, demography, 2014). In fact, enough with the figure of Rp 50 trillion, the benefits of ZIS will feel significant. Moreover, if the potential of ZIS fundraising can be excavated completely. This condition becomes a homework with zakat management institutions or agencies in both rural and urban areas to build awareness of Muslims that there is a great benefit behind the mandatory order of zakat (Efendi, 2014: 9). Because one of the most urgent constraints in ZIS fundraising is abyssal of social inequalities between powerful societies and weak economic societies and a lack of awareness of strong economic societies to assist materially to the economically weak communities. Therefore, the socialization and education of ZIS based on communitybased activities is still necessary.

Utilization of ZIS funds can be a direct and applicable solution for the weak economic community who suffered property deficits.Because he is one of the philanthropic and charity formulas in Islam. Coupled with the positive potential of the majority of Indonesians who often make ZIS as a motivation to donate some of their wealth with the aim of intention to the afterlife, in accordance with psychographic and situational motivation/characteristics in the country (Kasri, 2013: 63).

In the framework of participation in handling the difficult constraints of how to collect ZIS funds from the community and the lack of awareness of the strong economic community in distributing some of their assets in the form of ZIS, we are interested in studying about the optimization of ZIS fundraising in Mergolangu Village, Kalibawang, Kab. Wonosobo. Because the village Mergolangu located at the top of the mountains and its citizens still maintain the tradition of community-based activities of local wisdom.

\section{Research Methods}

This study uses a type of field research (field research), which is a descriptive analysis, means presented data and facts about optimization ZIS fund further analyze them to get answers from the formulation of the problem that has been created. This study is also equipped with a library research (library research) to produce a comprehensive description of the optimization of ZIS fundraising. 
The framework model used to analyze data and facts about the optimization of ZIS fundraising using Miles and Huberman interactive model (Moeleong, 1990: 18), it can be described as follows:

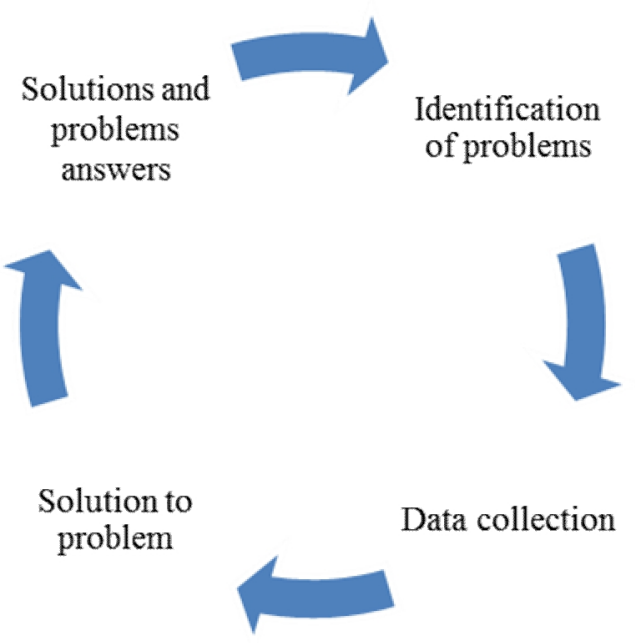

Figure 1. Data Analysis Process

\section{Result and Discussion}

\subsection{Characteristics of Mergolangu Village} Mergolangu Village Wonosobo regency is located between mountains, Mount Lanang, Mount Lawang, Mount Punuk Sarangan, Mount Memean, Mount Selikur and Mount Pupur. The distance to the village of Mergolangu from Semarang is about 6 hours. We can use the land route by means of transportation ie car, motorcycle or bus. But if we drive a car or bus, we can not directly reach the Village Mergolangu, unless we drive a Jeep or motorcycle. If we drive a car or bus, we can only get to SD (Elementary School) Depok then journeys followed by driving a truck or a vehicle that can pass through a fairly heavy field. Because the streets to be in passes quite badly damaged and still not repaired by the local government. On the way to the Village Mergolangu, our eyes will be pampered with natural scenery is still very beautiful and the air is still fresh without pollution.

The number of residents of Mergolangu Village is 690 people (Per Kepala Keluarga), the average of the last education of the people around is the primary school graduate, the average income of the villagers per month is around Rp 600.000,00 derived from businesses such as grocer, Small shop owner, Wood craftsmen, food industry makers (crackers). For sale out of the village, such as the annual sales of wood, the monthly sales of ginger, the daily sales of chili the majority of sales of chili by $60 \%$, almost $80 \%$ of the head of his family work as farmers and housewives mothers. The number of poor people in Mergolangu Village was also relatively high as many as 278 families. Nevertheless, community activities in Mergolangu Village are very well preserved, 
this can be found with the attitude of the number of citizens who interested with citizens who are very harmonious, the community gathering activities.

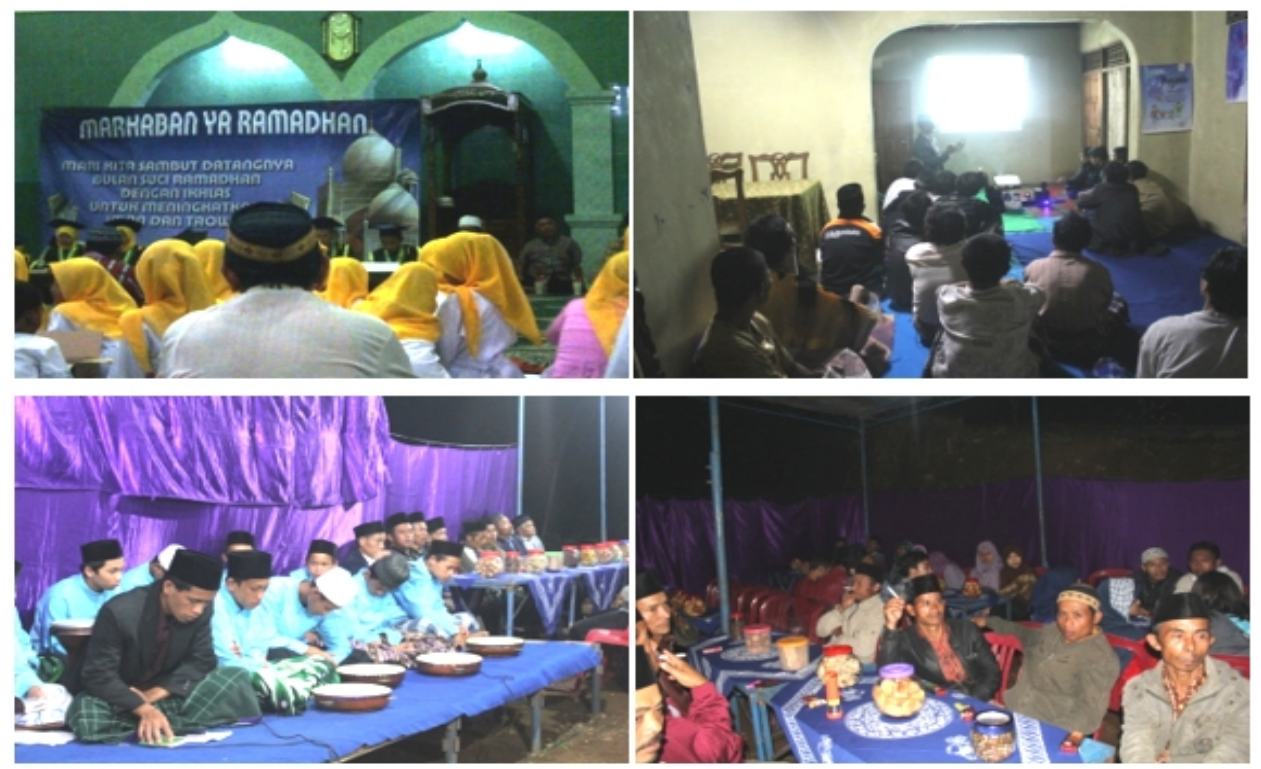

Picture 2. Several Activities of Mergolangu Citizens Communities

\subsection{Essence and Substance of ZIS}

In addition to the word zakat, in $\mathrm{Al}$ Qur'an zakat also called the name: Infaq, alms, Haq or Afuw (Prayitno, 2008: 43).

1. Words or designation Infaq, described in a letter al-Baqarah verse 267 :

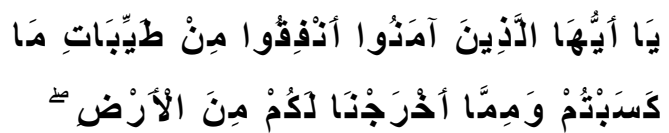

"Oye who believe, in the way of Allah spend in some of the results of your efforts."

2. Words or designation Zakat, among others listed in the letter al-Baqarah, verse 43:

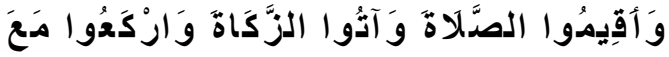

$$
\begin{aligned}
& \text { الرَّ اكِعِينَ }
\end{aligned}
$$

"And establish regular prayer, pay the poor-due, and bow with those who bow."

3. The word or title Haq, is mentioned in Surat al-An'am verse 141:

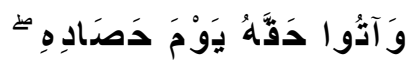

"and let it be his right on the day of plucking the result (with zakat issued),"

4. Words or designation afuw, stated in the letter al-A'raf verse 199:

$$
\begin{aligned}
& \text { خُذِ الْعَفَوَ وَأَهُرْ بِالَعُرْفِ وَأَعْرضْ عَن } \\
& \text { الجَاهِلِِينَ }
\end{aligned}
$$

Take afuw (zakat) and summon the kind and turn away from those who are ignorant (uncivilized). 
5. Words or designation alms, described in the letter at-Tawbah verse 60:

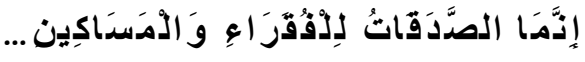

"Verily alms-charity was for poor people and poor .....

Etymologically word shadaqah comes from Arabic and is a basic word (mashdar) of Zaka which is holy, blessing, grow, and commendable. While in terminology Zakat is an obligation of a Muslim who is able economically to expend most of his wealth to the Muslims who need it in the period and a certain amount that taught by Islam (Qaradawi, 1995: 34).

When viewed from the meaning etymologically and terminology charity, it can be seen that the link intimately meaning, namely that any property or assets which have been issued their zakat will be holy, clean, good, blessing, grow and thrive. And this act of zakat is also attributed to the muzakki (the tithe), meaning it can purify the person who issued it and cultivate goodness/reward (Muhammad and Ridwan, 2005: 42).

Zakat is an obligation for Muslims who are able, therefore position of charity has a very important and strategic for muzzaki and mustahiq and mankind in general. So the essence and substance of the most important of zakat, infaq and shodaqoh (ZIS) is the fairness of income distribution ('adālatu tauzi') taken from people who have a surplus property to be distributed to the deficit treasure (eight ashnaf), as religious scripts Al-Qur'an Surah al-Tawbah (9): v. 60, which means: "The zakat is only for the poor, the poor, the administrators of zakat, the mu'allaf who is persuaded, To [liberate] slaves, to those who are in debt, for the way of Allah and for them are on their way. “

ZIS also has a purpose to make blessings in possessions owned by a person and to contribute to the social life of Muslim society about their welfare. Because essentially, in every Muslim's possessions there is a right and a part for the poor. It has been reflected from the word of God which is related to the command of carrying out zakat. Then strengthened also with the hadith and sunnah of Prophet Muhammad SAW regarding ZIS (Andriyanto, 2011: 30).

\section{Goal of Implementation of the ZIS}

In addition to one of the pillars of Islam that dimension social justice (Sabiq, 1982: 276). Zakat is a worship associated with 
fellow human beings (horizontal) because human life always coexists in harmony and peace lovingly among others to keep a balance of life, balance between individual and social, also balance in relation with God and neighbor (Ridwan, 2005: 204 ). Zakat, infaq, alms, and waqf are a great potential possessed by Muslims to overcome social problems among peers but this potential has not yet been utilized optimally to overcome these problems (Hafidhuddin, 201l: 4). Meanwhile, according to the Indonesian government through the Ministry of Religious Affairs explained that the ZIS has a goal to:

1. Elevate the poor and help him out of the hardships of life and suffering.

2. Helps solve the problems faced by gharimin, ibnussabil, and other mustahiq.

3. Expanding and fostering fraternal races among Muslims and humans in general.

4. Eliminate the miserliness of the property owner.

5. Cleans the envy and envy (social jealousy) of the hearts of the poor.

6. Bridging the gap between the rich and the poor in a society.
7. Develop a sense of social responsibility in a person, especially on those who have property.

8. Educating the man to discipline fulfill obligations and surrender the rights of others to him.

\section{Frame Work ZIS Socioeconomic Seen} From the Side

Viewed from the economic side, ZIS is an act of giving part of the wealth of the group of people who are surplus to the group of people who can not afford (deficit). The transfer of this treasure has the same meaning as the transfer of economic resources.This action should result in a change in the status of the person whose economic deficit is economic; For example, someone who receives ZIS funds can use it to meet the needs of everyday life can even be used for business capital that is productive. Therefore, although ZIS is essentially a service to God, it can also impact social and economic aspects of society.

According to Rahardjo, using a socioeconomic approach, ZIS could develop into becoming social concept (mu'amalah), the concept of how society should be run social 
life by helping each other and giving, and how the community should meet their needs in a way that Lawful and good. Because of this, the frame work in the social doctrine of the ZIS-economic perspective is very important to implement Shari'ah (Muhammad Ridwan, 2005: 42).

ZIS frame work is also closely linked to the nature of community development is to welfare and prosperity. Because basically, the development of ZIS covers various aspects in multicultural society life But still have the ultimate goal of the welfare of society. In the end, ZIS also contributes to improving and improving the quality of life of the people, since the creation of prosperity must always proceed in order to produce progress and be well oriented in the future (Hidayatullah and Thomas, 2011: 33). Which is in line with the message of the Qur'ân who wants the creation of a public, egalitarian and peaceful society by living the rules and norms that exist in the Qur'ân, the hadith and sunnah of the Prophet SAW (Asroni, 2011: 367).

\section{ZIS Management Model in the village} of Wonosobo Mergolangu

According to Law no. 38 of 1999 on the Management of Zakah, Article 4 states that the management of zakat is based on faith and piety, openness and legal certainty in accordance with Pancasila and the 1945 Constitution. Article 5 reads: Amil Zakat Body has the main duty of collecting, distributing and utilizing zakat In accordance with religious provisions. In addition, the Amil Zakat Board can also receive property other than zakat, such as infaq, alms, grants, wills, inheritance, and kafarat.

Generally, there are two opinions about the problem of utilizing ZIS funds. First, that ZIS is more consumptive and distributed directly to the party entitled to receive zakat funds (eight groups). Secondly, that the utilization of ZIS funds contains a very wide socioeconomic aspect is not merely consumptive (Muhammad and Ridwan, 2005: 102).

To be able to effectively utilize and disseminate ZIS funds, socio-economic aspects need to be emphasized; ZIS funds should not be prioritized for consumptive, but ZIS funds should be productive. There are two systems utilization of ZIS is by using two approaches: First, the partial approach, in this case the utilization of ZIS funds given directly 
to mustahiq incidental, this approach see the condition mustahiq urgent get help, perhaps because of his condition critical, but it is more Consumptive. The second approach, a structural approach, an approach that has weighed on the allocation of funds ZIS is produces the Dhu'afa (the weaks) by providing continuous funding aimed at keeping the poor to overcome their poverty, and even expected that later they can be muzakki, no longer existed mustahiq ( Recipient of zakat) but changed his profession to become a donor of ZIS (Qadir, 2001: 223).

While in the management of ZIS funds in Mergolangu Village, ZIS administrators in Mergolangu Village use a model of management and distribution of ZIS funds based on community activities and managed transparently and known by the whole community. So the ZIS administrators in Mergolangu Village always gain the trust and direct control of the surrounding community. Through the development of ZIS fund raising programs integrated with community activities, the distribution of ZIS funds can also be targeted to the poor who really need it. The Mergolangu Village community has a direct role as the supervisor of all programs undertaken by the ZI Village Board of Mergolangu as its ZIS fund management has a simple motto "from the Mergolangu Village community, by Mergolangu Village community and for Mergolangu Village community".

The development of ZIS in areas such as Mergolangu Village is an integral part of national development. Because both have processes for better and planned change in improving the welfare and prosperity of the community, this process always involves community activities and is supported by the support of surrounding communities in various aspects (Prishardoyo, 2008: 1).

\section{Fundraising Process ZIS in the village Mergolangu}

Referring to government regulations through Law no. 38 of 1999 on the management of zakat, which states that every management of zakat, infaq and alms such as Badan Amil Zakat (BAZ) and Lembaga Amil Zakat (LAZ) in Indonesia to be truly trustworthy, honest, skilled, professional and responsible in performing duties of service as Administrators (Amil) in BAZ and LAZ (Andriyanto, 2011: 44).Therefore the managers of ZIS in the village Mergolangu required changing the 
lives of people around who formerly existed as mustahiq increased their status to muzakki. Because the effectiveness of the success of community activities in the village is usually determined by the good or bad role of the managers and the good or bad function of group members who entered the membership (Ridwan, 2012: 215). In the ZIS organization in the country, its success is determined by whether good or bad methods used in ZIS fund raising, the selection process of candidates for zakat (mustahiq) and the distribution of funds ZIS.

Therefore, traditional ZIS management methods such as direct muzakki and mustahiq distribute their funds without going through the 'amil (ZIS board Mergolangu village) less rapidly in achieving the goals of ZIS itself. ZIS in Mergolangu Village is collected and utilized through 'amil (ZIS Village Mergolangu administrators) taking into account the conditions of recipients to avoid prolonged poverty and controlled by the community directly. Because the normative ZIS as a source of funds of Muslims should be able to create prosperity and realize social justice and improve the quality of life of the underprivileged.

The source of ZIS funds in Mergolangu Village comes from the community or individuals (business actors), groups, organizations, government assistance that will be used to finance the programs and activities of the village which aims to familiarize people with helping each other and helping. ZIS in fundraising committee to apply the theories and concepts of 'urf (local wisdom). For example, ZIS administrators inventory the various local community activities around Mergolangu Village residents, then filter out any activities or associations that can be optimized for ZIS fund raising. Then using a simple ZIS fund-raising method based on local community activities. Examples of the method of piggy bank and an integrated card method on any activities or associations of citizens that allow for the implementation of this method, such as monthly meeting, the cyclical anniversary of the Islamic Day, recitals or reading yasin (called yasinan) lessons and so forth. Even to conserve raw materials and embodies the concept of the ZIS board go green piggy bank or card making installments from 
secondhand materials such as jars, used paper and so forth.
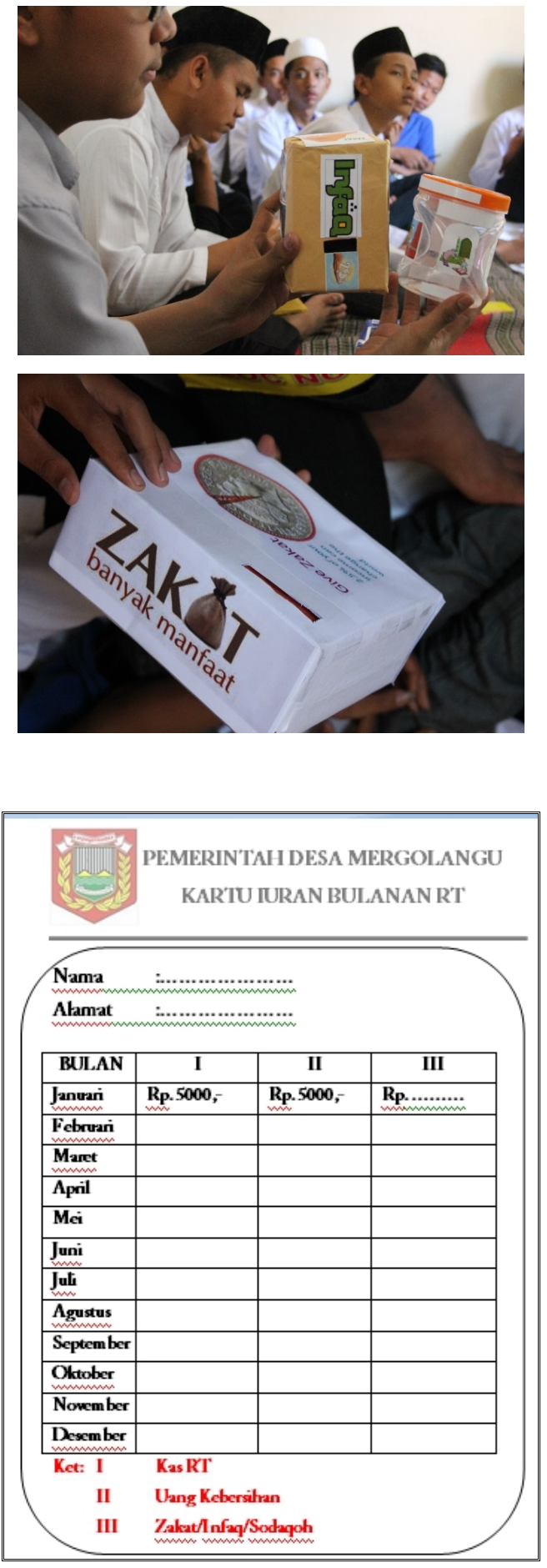

Picture 3. Modified ZIS Inflatables With Integrated Community Activities
This time the target aimed by the board to be the target muzakki ZIS besides ordinary village people are timber companies, entrepreneurs and businessmen palm sugar ginger agricultural products. This target is set by ZIS administrators because they have financially financial income belonging to the category "Mandatory Zakat" and almost 100\% of Mergolangu Village residents are Muslims.

\section{Effect of ZIS on the Economy of Villagers Mergolangu}

The allocation of ZIS successfully collected by the board can be used as a form of capital or additional capital for households and micro/small businesses, and also to help alleviate the cost of education, and to assist the consumptive needs of incomplete villagers. Thus, ZIS has an enormous influence on the various things of citizen life, among them is the influence in the economic field. The effect of other ZIS is the sharing of income or income from the society able to the society is less even not able in a fair and equitable.

Ideally, if the management of ZIS is done professionally and well, in fact it can help the economy of the society is less even not 
able and help the government in improving the nation's economy, that is the economic empowerment of the people in accordance with the missions it carries. Among these missions are:

1. The mission of economic and business development that is guided by a common and universal measure of economy and business.

2. Mission of business and legal ethics;

3. Mission to build economic power for Islam, so that become source of fund support propagation of Islam (Muhammad and Ridwan, 2005: 55).

\section{Conclusion}

In this concluding section, it can be concluded that ZIS fund raising through community-based activities in Desa Mergolangu has been running optimally and quite successfully at the lower levels. This is supported by the high intensity of the presence of citizens in the implementation of community activities, coupled with the findings in the field that Mergolangu villagers still always uphold tradition or customs oriented to the harmony of citizens and local wisdom.

Thus, automatically The collection of ZIS funds in Mergolangu Village through community activities is very effective to be applied in rural communities that in fact the majority convert to Islam. The usual method used to collect ZIS funds is through the method of ZIS piggy birds integrated with community activities of Mergolangu villagers and methods of ZIS contribution card integrated with community activities of Mergolangu villagers.

\section{BIBLIOGRAPHY}

Ali, Mohammad Daud. 1988. Economic System of Islam Zakat and Waqf. UI Press. Jakarta.

Andriyanto, Ershad. 2011. "Zakat Management Strategy in Poverty Alleviation". Journal Walisongo. Volume 19, Number 1.

Asroni, Ahmad. 2011. "The Thought of Ahmad Syafii Maarif About State and Islamic Sharia in Indonesia”. Journal of Millah. Vol. X. No. 2.
Ministry of Religious Affairs. 1982. Development Project Zakat and Awqaf, Zakat Guidelines (4). Ministry of Religious Affairs.Jakarta.

Hafidhuddin, Didin. 2011. "The Zakat Organization's Strategic Role in Strengthening Zakah in the World". Al-Infaq Islamic Economic Journal. Vol. 2. No. 1.

Hidayatullah, Syarif and Thomas Djaka SBW. 2011. 
Empowerment Model Through Local Economic Development (Study on SMEs Craftsmen in Malang)". Journal of Economics. Vol. 4. No. 1.

http://kabar24.bisnis.com, accessed on May 5, 2015.

http://www.republika.co.id, accessed on May 5, 2015.

Https://www.rumahzakat.org/wpcontent/uploads/2014/12/RZ MAGZ-15-DESEMBER.pdf

Kasri, Rahmatina Awaliah. 2013. "Giving Behaviors in Indonesia: Motives and Marketing Implications for Islamic Charities". Journal of Islamic Marketing. Vol. 4 No. 3.

Muhammad and Ridwan Mas'ud. Zakat 2005. Economic Empow erment and Poverty Instruments Ummat. UII Press. Yogyakarta.

Prayitno, Budi. 2008. "Optimizing Zakat Management at Regional Amil Zakat Agency (Review on Amil Zakat Agency of Muna Regency of Southeast Sulawesi Province)". Thesis. Magister Program of Law Science, Diponegoro University, Semarang.

Prishardoyo, Bambang. 2008. "Analysis of Economic Growth and Economic Potential of Gross Regional Domestic Product (PDRB) of Pati Regency Year 2000-2005". TRACES Journal of Economics and Policy. Volume l. Number 1 .
Qadir, Abdurrachman. 2001. Zakat (In Mahdah and Social Dimensions). Ed.l. Cet. 2. RajaGrafindo Persada. Jakarta.

Qardhawi, Joseph. 1995. Tips for Alleviating Poverty Islam. Gema Insani Press. Jakarta.

Ridwan, Mochamad. 2012. "Strengthening the Economics of Group-Based Societies". Journal of Development Economics. Volume 13. Number 2.

Ridwan, Muhammad. 2005. Management of Baitul Maal Wa Tamwil (BMT). UII Press. Yogyakarta.

Rosyadi, Imron and Didit Purnomo. 2012. "Household Food Security Level in Disadvantaged Villages". Journal of Development Economics. Volume 13. Number 2.

House of Zakat. RZ 2014. Magazine. Issue 15 Year 2. December.

Sabiq, Sayyid. 1982. Fiqh al-Sunnah, Volume I. Dar al-Fikr. Beirut.

Saefuddin, Ahmad M. 1987. Economy and Society in the Islamic Perspective. CV Rajawali. Jakarta.

Tarar, Ayesha and Madiha Riaz. 2012. "Impact of Zakat on Economy: Structure and Implementation in Pakistan". Journal of Economics and Sustainable Development. Vol.3. No. 10.

Law No. 38 of 1999 on the Management of Zakah. 